\title{
Study of Ground Vibration Reduction Using Fault Tree Analysis Method on Blasting Activity in PT. Semen Baturaja Persero, Tbk.
}

\author{
Jihan F.Lubis ${ }^{1}$, Taufik Toha ${ }^{2}$, Ngudiantoro ${ }^{3}$ \\ ${ }^{1}$ Mining Engineering, Faculty of Engineering, Sriwijaya University, Palembang 30319, \\ ${ }^{1}$ Coal Mining Engineering, Polytechnic Akamigas Palembang 30257, \\ ${ }^{2}$ Mining Engineering, Faculty of Engineering, Sriwijaya University, Palembang 30319, \\ ${ }^{3}$ Mathematics, Faculty of Mathematics and Natural Science, Sriwijaya University, Palembang 30319
}

\begin{abstract}
Limestone mining activities at PT. Semen Baturaja Persero, Tbk use blasting activity that produces ground vibrations. Based on the measurement result on vibration level, the maximum value for vibration is $4.66 \mathrm{~mm} / \mathrm{s}$. The results of the data show that the level of emission has exceeded the standard limits for second class buildings (3 mm/s) based on (SNI) 7571: 2010 while the blasting activity is only 175-300 $\mathrm{m}$ from the nearest settlement. Fault Tree Analysis is used to analyze undesired events in a system or work set. Reconstruction of Fault Tree Analysis with Boolean algebra yields 5 event combinations that have the highest chance of generating ground vibrations. The event with the highest failure rate is X11 (the number of bursting holes simultaneously) with failure rate of 0.813 and X12 (fast timing delay) with failure rate $(0.750)$. The USBM formulation obtained $3 \mathrm{~mm} / \mathrm{s}$ vibration results when the number of bursting holes was reduced from 5 holes to 2 holes/delays with a quantity of $43 \mathrm{~kg}$ /delay. Based on Shotplus simulation, the company is advised to replace the blasting delay system from electricity to electronics to produce minimal explosion of ground vibration so as not to damage the environment.
\end{abstract}

\section{Keywords: Blasting, flyrock, Vibration, powder factor}

\begin{abstract}
Abstrak (Indonesian)
\section{Introduction}

Blasting is one of the rock excavation methods used to destroy hard materials of large size into smaller materials that can be easily transferred by heavy equipment ${ }^{[1]}$. Ground vibration is a wave that moves in the ground caused by the source of energy. Such energy sources can come from nature, such as earthquakes or human activities, one of which is explosive activity. ${ }^{[2]}$ Ground vibrations at some level may cause structural damage around the blasting site. Therefore, the state of danger that may be caused by blasting operations cannot be ignored. ${ }^{[3]}$

Several studies have been done in analyzing and attempting to
\end{abstract}

Proses peledakan batu kapur di PT. Semen Baturaja Persero, Tbk, menghasilkan efek peledakan berupa getaran tanah. Berdasarkan hasil pengukuran terhadap tingkat getaran didapatkan nilai maksimum untuk getaran sebesar $4.66 \mathrm{~mm} / \mathrm{s}$. Hasil data menunjukkan tingkat geraran telah melebihi batas standar untuk bangunan kelas dua $3 \mathrm{~mm} / \mathrm{s}$ (SNI) 7571:2010, sementara kegiatan peledakan hanya berjarak 175$300 \mathrm{~m}$ dari pemukiman terdekat. Fault Tree Analysis digunakan untuk menganalisis kejadian (undesired event) yang tidak diinginkan dalam sebuah sistem atau rangkaian pekerjaan. Rekonstruksi Fault Tree Analysis dengan analisis aljabar Boolean menghasilkan 5 kombinasi event yang memiliki peluang tertinggi untuk menghasilkan getaran tanah. Event dengan tingkat kegagalan tinggi adalah event X11(jumlah lubang meledak bersamaan) dengan laju kegagalan 0.813 dan X12 (delay timing cepat) dengan laju kegagalan (0.750). Formulasi USBM memperoleh hasil getaran $3 \mathrm{~mm} / \mathrm{s}$ apabila jumlah lubang yang meledak bersamaan direduksi dari 5 lubang menjadi 2 lubang perdelay dengan kuantitas $43 \mathrm{~kg} /$ delay. Berdasarkan simulasi softwate shotplus perusahaan disarankan untuk mengganti sistem delay peledakan dari listrik menjadi elektronik untuk menghasilkan peledakan yang minim getaran tanah sehingga tidak merusak lingkungan.

Article History:

Received: 7 October 2017

Accepteed: 9 January 2018

DOI: $10.22135 /$ sje.2018.3.1.27-30

*Corresponding Author: jehanfarhan.jl@gmail.com reduce the ground vibrations, such as H.S Venkatesh has analyzed the reduction of the blasting vibration level by making a trench on the open pit ${ }^{[4]}$. Maryuna R, using a blast-holes presplitting technique to reduce the level of vibration ${ }^{[3]}$. Joris $\mathrm{P}$, study the effect of circuit pattern on vibration level ${ }^{[5]}$.

This research was conducted to find out the cause of high ground vibration with fault tree analysis approach. The Fault Tree Analysis (FTA) method is a technique used to identify risks that contribute to failure. This method is done with a top down approach, which begins with the assumption of failure of the top event then detailing the causes of failure to a root cause ${ }^{[6]}$.

Ground vibration samples were taken from the blasting activity at PT. Semen Baturaja Persero, Tbk. It is hoped that the ground vibration analysis with FTA (Fault Tree Analysis) method can formulate the main cause of high ground vibration and the effort needed to minimize it.

\section{Experimental Section}

\subsection{Research Sites}

Vibration data retrieval is done in SMP 7 Pusar area, PT. Semen Baturaja Persero, Tbk. The location selection is based on the con- 


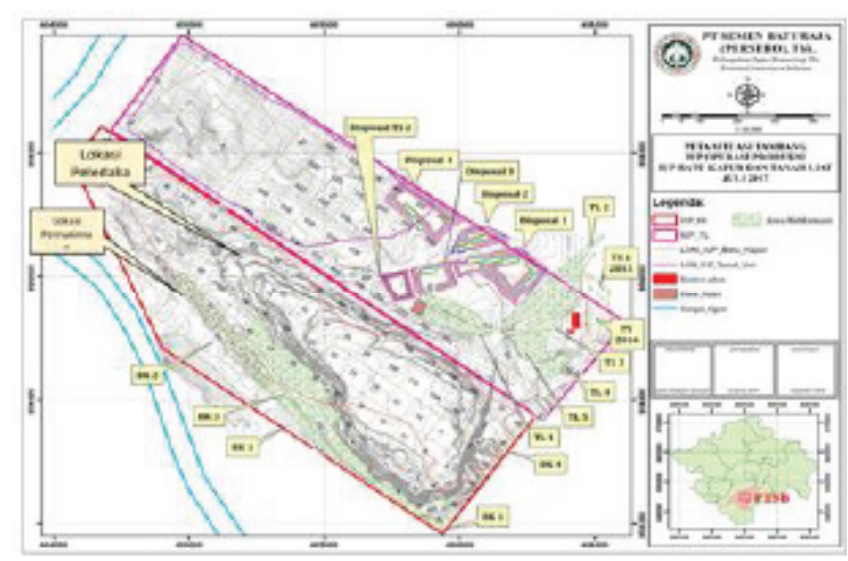

Figure 1. Research Location Quarry limestone at Baturaja East $\mathrm{OKU}$

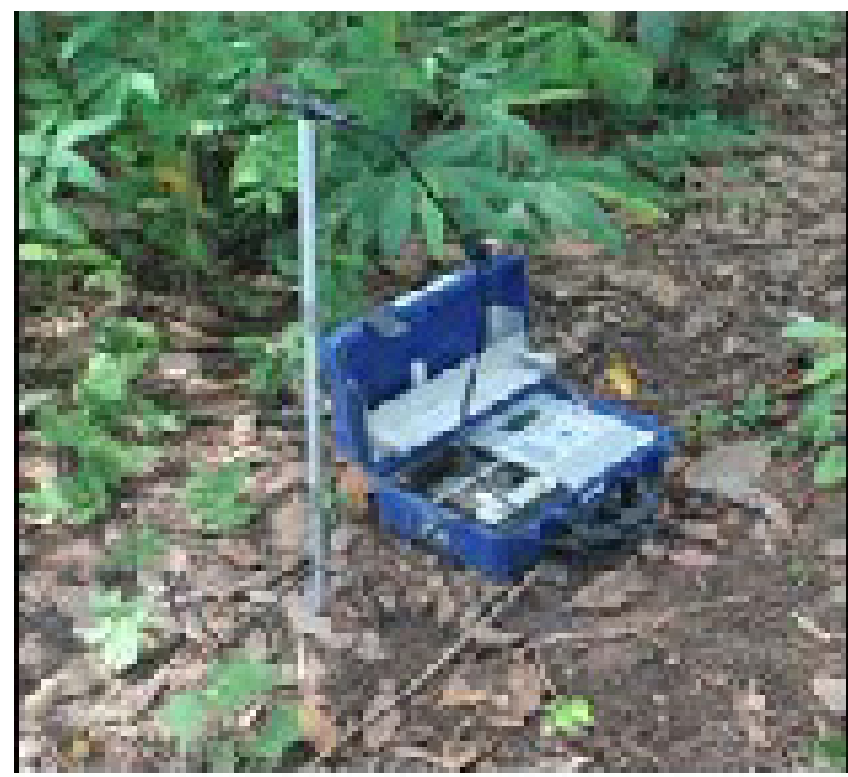

Figure 2. Vibration and noise gauge (Blastmate III)

sideration of the distance of the nearest building (the building of the residents) with the location of the blasting ${ }^{[7]}$. The distance of the blasting location to the nearest settlement is 180 meters. (Figure 1).

\subsection{Tools and Materials}

Ground vibrations data was taken with daily frequency using vibration and noise gauge called Blastmate III ${ }^{[9]}$ (Figure 2). The measurement data is then incorporated into the blastware software, to obtain a graph of measurement results. Another software used is Shotplus, this software is a blasting design tool used to reconstruct blasting delay used in blasting activity ${ }^{[10]}$.

\subsection{Flow Chart of Research}

The research stages as follows;

\section{Results and Discussion}

\subsection{Ground Vibrations}

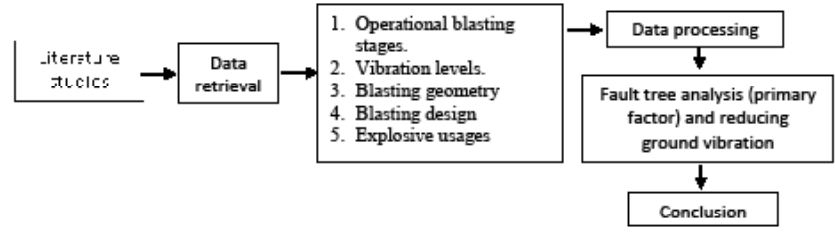

Figure 3. Flow Chart of Research

The percentage data accumulated from vibrations above $1 \mathrm{~mm} / \mathrm{s}$ to $5 \mathrm{~mm} / \mathrm{s}$, the percentage of vibration levels from the blast measurement results can be seen in (Figure 4).

The vibration level of 3 to $5 \mathrm{~mm} / \mathrm{s}$ is exposed in the range of $23.08 \%$, with maximum level is $4.66 \mathrm{~mm} / \mathrm{s}$. It's already exceed the standard ground vibration with maximum value is $3 \mathrm{~mm} / \mathrm{s}$ for category 2 building, referred to SNI 7570: $2100^{[11]}$. The results of the above data show the level of vibration blasting at risk to give damage impact to society environment. This situation is further aggravated by blasting activities that are too close to the settlement.

\subsection{Reconstruction of FTA trees from ground vibration data}

Fault tree analysis for undesired event ground vibration is built based on actual parameters of the field which are then matched with standard parameters theoretically through literature study ${ }^{[12]}$. (Figure 5)

The event that builds the fault tree analysis model of the vibration level is categorized into the symbols of the letters, shown in the following table.

Main event is a failure in the blasting process symbolized by the letter " $\mathrm{T}$ " is blasting vibration. Blasting vibrations can occur when one of the below events is "A1" natural influences and "A2" human error occurs, or both factors occur so that the basic event is associated with the "OR" gate. The blast vibration analysis tree is built on the "and" and "OR" principles of gate logic used in the FTA analysis ${ }^{[13]}$.

The fault tree analysis is followed by Boolean algebra formulation. The purpose of this analysis is to find the minimum cut set. A cut set is defined as a basic event (event basis) which, when it happens, will result in a top event. Fault tree analysis on vibration produces minimum cut set (table 2)

The combination of events is then formulated by the formula [12];

$$
I_{\varnothing}(i)=\sum_{X_{i} \in K_{j}} \frac{1}{2^{n_{j}-1}}
$$

Where $x i$ is (h) basic occurrence of the fault tree $\mathrm{Kj}$ is

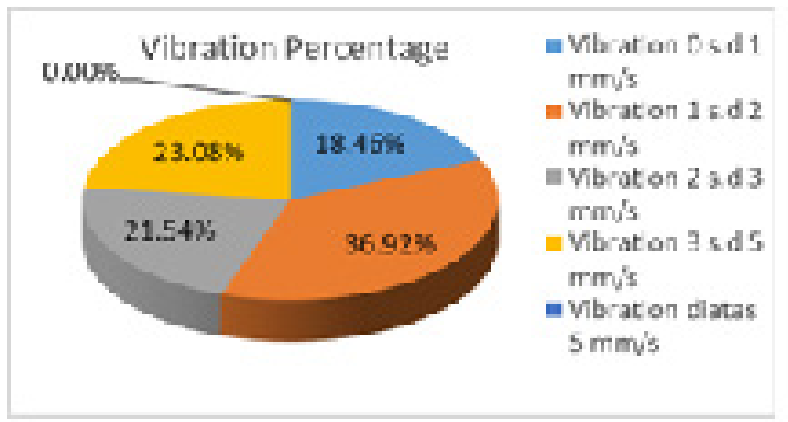

Figure 4. Vibration Percentage 
Table 1. Description of FTA Tree Vibration

\begin{tabular}{cllll}
\hline \multicolumn{1}{c}{ Event } & Description & Event Fault Tree Analysis Description \\
T & Ground Vibrations & Event & Description \\
A1 & Natural Influence & X1 & Weather Cloudy \\
A2 & Human Error & X2 & Topographic Condition \\
B1 & Geological Condition & X3 & Rock Condition \\
B2 & Failure Blasting Operations & X4 & Minimal supervision \\
B3 & Wrong Blasting Design & X5 & Less planning and control \\
C1 & Negligence in work & X6 & Overloading Explosives \\
C2 & Geometry applied incorrectly & X7 & Short Stemming \\
D2 & Large Quantity of mass/delay & X8 & Short Burden and Spacing \\
D1 & Blast geometry deviation & X9 & Wrong initiation point \\
& & X10 & Burden near to freeface \\
& & X11 & Hole exploded simultaneously \\
\hline
\end{tabular}

Table 2. Minimal Cut Set from Vibration Fault Tree

\begin{tabular}{cccc}
\hline \multicolumn{3}{c}{ Minimal Cut Set } \\
No & \multicolumn{1}{c}{ Formula FTA } & No & Event Combination \\
1 & $\mathrm{~T}=\mathrm{A} 1+\mathrm{A} 2$ & 1 & $\mathrm{X} 1$ \\
2 & $\mathrm{~A} 1=\mathrm{B} 1+\mathrm{X} 1$ & 2 & $\mathrm{X} 2$ \\
3 & $\mathrm{~B} 1=\mathrm{X} 2+\mathrm{X} 3$ & 3 & $\mathrm{X} 3$ \\
4 & $\mathrm{~A} 2=\mathrm{B} 2+\mathrm{B} 3$ & 4 & $\mathrm{X} 4 . \mathrm{X} 6$ \\
5 & $\mathrm{~B} 2=\mathrm{X} 4 . \mathrm{C} 1$ & 5 & $\mathrm{X} 4 . \mathrm{X} 7$ \\
6 & $\mathrm{C} 1=\mathrm{X} 6+\mathrm{X} 7$ & 6 & $\mathrm{X} 5 . \mathrm{X} 11$ \\
7 & $\mathrm{~B} 3=\mathrm{X} 5 . \mathrm{C} 2$ & 7 & $\mathrm{X} 5 . \mathrm{X} 12$ \\
8 & $\mathrm{C} 2=\mathrm{D} 1+\mathrm{D} 2$ & 8 & $\mathrm{X} 5 . \mathrm{X} 8$ \\
9 & $\mathrm{D} 1=\mathrm{X} 11+\mathrm{X} 12$ & 9 & $\mathrm{X} 5 . \mathrm{X} 9$ \\
10 & $\mathrm{D} 2=\mathrm{X} 8+\mathrm{X} 9+\mathrm{X} 10$ & 10 & $\mathrm{X} 5 . \mathrm{X} 10$
\end{tabular}

Table 3. Value of failure rate and level of reliability of vibration factor

\begin{tabular}{cccccc}
\hline Event & $\mathrm{X} 8$ & $\mathrm{X} 9$ & $\mathrm{X} 10$ & $\mathrm{X} 11$ & $\mathrm{X} 12$ \\
\hline $\begin{array}{c}\text { Failure } \\
\text { Rate }\end{array}$ & 0.594 & 0.5 & 0.688 & 0.813 & 0.75 \\
$\begin{array}{c}\text { Value Re- } \\
\text { liability }\end{array}$ & 0.552 & 0.607 & 0.503 & 0.444 & 0.472 \\
\hline
\end{tabular}

the minimum cut set in the fault tree, $\mathrm{nj}$ is the frequency of the minimum cut set.

The main cause of failure (basic event) of the main event level of ground vibration analyzed in fault tree analysis can be calculated as follows;

$$
\begin{aligned}
& I \varphi(1)=I \varphi(2)=I \varphi(3)=1 \\
& I \varphi(6)=I \varphi(7)=I \varphi(8)=I \varphi(9)=I \varphi(10)=I \varphi(11)=I \varphi(12)=1 x \\
& \frac{11}{22}=0.5
\end{aligned}
$$

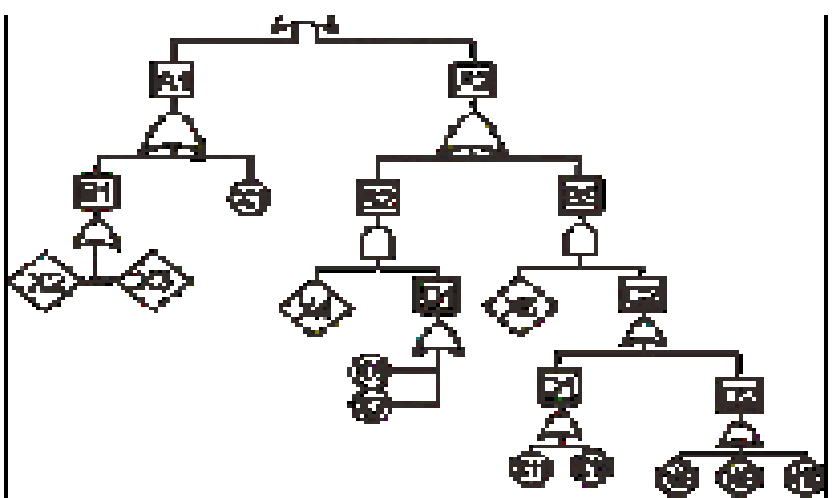

Figure 5. Model FTA Vibration

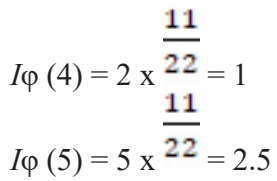

The combination of high frequency events involves X5 events "less planning and control" against actual blasting conditions in the field. The X5 combination follows other events, based on the failure rate test of the factors affecting the occurrence of vibration, the reliability value is obtained as the following table;

The table above shows that the weakest reliability value indicates the X11 with the parameter of the number of burst holes simultaneously and X12 (Fast Timing Delay).

\subsection{Efforts to minimize Ground Vibrations}

Based on the USBM (United States of Bureau of Mines) formulation ${ }^{[14]}$, with a PPV limitation of $3 \mathrm{~mm} / \mathrm{s}$, as a security consideration, the scale distance of 25 and the maximum of explosive probes that can be used is $43 \mathrm{~kg} /$ delay at a distance of $170 \mathrm{~m}$. With explosive capacity of $16 \mathrm{~kg} /$ hole at a depth of $6 \mathrm{~m}$ hole, the number of explosive burst holes shall be 3 holes / delay only. In the $9 \mathrm{~m}$ depth explosion hole with a capacity of $20 \mathrm{~kg} /$ hole, the blasting 


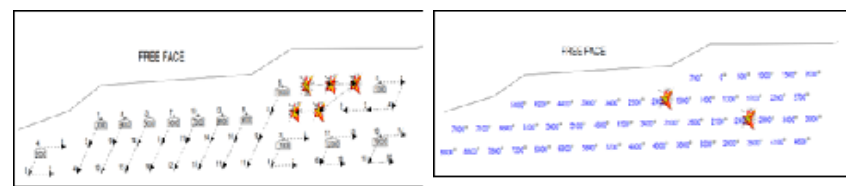

Figure 6. Shotplus Simulation compare between electric delay (left) and electronic delay (right)

per delay can only be done as much as 2 holes/delay.

Limitations in the use of electrical detonators make it difficult to reduce the number of bursting holes simultaneously. By using electronic detonators, through simulation with the shotplus-i software version 4 the number of detonations can be reduced to 2 holes per delay from 5 holes per delay (figure 6).

\section{Conclusion}

The measurement result of ground vibration level in quarry of limestone shows tendency of negative impact to society environment. The percentage of vibration above $3 \mathrm{~mm} / \mathrm{s}$ reach $23,08 \%$. The blasting distance close to the community settlements will further magnify the negative effects of the blasting effect.

Fault Tree analysis on ground vibration conclude that the main cause of failure is "less planning and control" and combination to other event such as "the number of burst holes simultaneously" and "fast timing delay".

The shotplus simulation showed that electronic detonators can reduce the number of burst holes from 5 holes/delay to 2 holes/delay. To reduce the level of vibration, the company may consider to replace the blasting delay system from electricity to electronics to produce minimal explosion of ground vibration so as not to damage the environment.

\section{References}

L.J. Carlos. Drilling and Blasting of Rocks, A.A Balkema; Rotterdam, 1995, pp. 98-105.

Dowding, Charles H. (1984). Blast Vibration Monitoring and
Control. Northwestern University, USA.

Maryura, R. (2004). Study Of Ground Vibration Level Reduction In Blasting Operations Interburden B2-C Coal Mining Air Laya Pt. Bukit Asam (Persero), Tbk Tanjung Enim, Journal of Mining Engineering, Sriwijaya University.

H.S. Venkatesh, "Reduction of Blast Induced Ground Vibrations with Open Trenches in Surface Mines" In; the 12th International Conference of International Association for Computer Methods and Advances in Geomechanics (IACMAG), 2008, pp. 5-8

Joris, P. (2013), Circuit Pattern Analysis Of Influence Of Blasting Ground Vibration Level At Pt. Cipta Kridatama Jobsite Pt. Multi Harapan Utama, Kabupaten Kutai Kartanegara, East Kalimantan, Undergraduate Thesis, Mulawarman University.

Richma, Y.H. "Perbaikan Kualitas Produk Keraton Luxury Di Pt. X Dengan Menggunakan Metode Failure Mode And Effect Analysis (FMEA) Dan Fault Tree Analysis (FTA)", Jurnal Online Institut Teknologi Nasional, Vol.03, No.03, Juli 2015.

A.Kahriman."Analysis of ground vibrations caused by bench blasting at Can Open-pit Lignite Mine in Turkey", Environmental Geology journal, vol.41, pp. 653-66, February, 2002.

L.B Wesley, "The Fundamental of Blast Design", in Workshop of the Golden West Chapter of the International Society of Explosive Engineers, 1999, pp. 1-5.

Sundoyo, "Kajian Ground Vibration Dari Kegiatan Blasting Dekat Kawasan Pemukiman Untuk Mencapai Kondisi Aman Di Penambangan Batubara”, Jurnal Geologi Pertambangan. Vol.1, pp. 1-8, Februari, 2015.

T. Simon. Explosive Engineer Manual Hand Book, AEL Mining Service South Africa., 2011, pp 20-50.

Eltschlager K, Clarck D, Sthepens W, Best D. Blaster Training Module, Office of Technology Transfer, Orica Mining Service, 2008, pp 56-60.

Z. Zilong, "Safety Evaluation of Blasting Flyrock Risk with FTA Method", Chinese Journal of Rock Mechanics and Engineering, vol.13, pp.23-28, Mei. 2004.

Fitria, M. "Penggunaan Aljabar Boolean Dalam Menganalisis Kegagalan Pada Fault Tree Analysis", Jurnal Matematika Murni dan Terapan Vol. 3 No.2 Desember 2009: 27 - 38

Anon. Orica Mining Blasting Manual Guidance, Blaster Training Module, Office of Technology Transfer, Orica Mining Service, 2008, pp 18-25. 